\title{
Kecakapan Berpikir Dalam Konteks Pendekatan Pembelajaran Pada Kurikulum Sekolah Di Indonesia
}

\author{
Marwan Salahuddin dan Fatimatul Asroriyah \\ Institut Agama Islam Sunan Giri (INSURI) Ponorogo
}

\begin{abstract}
The thinking skills are indispensable in the context of the learning approach, as it is a scientific thinking process aimed at growing the expected personality. It also affects the learning process and the ability to develop its goals through strengthening attitudes, skills and knowledge in an integrated way. The process includes activities: observing, asking, trying, reasoning, and communicating. In the course of the school curriculum in Indonesia and its learning process, the strengthening of cognitive and skill aspects is still dominant, while the attitude (spiritual and social) is still lacking, but this attitude will support the learning activities oriented to cultivation of character. Because the curriculum and the previous learning process still appear to be opposite and have not indicated the process of achieving competence in the attitude aspect, the curriculum of the school applied today is tailored to that need. So as to accommodate the elements of personality that include: beliefs, values, and behavior as a whole.
\end{abstract}

\begin{abstract}
Abstrak
Kecakapan berpikir sangat diperlukan dalam konteks pendekatan pembelajaran, karena merupakan proses berpikir ilmiah yang bertujuan menumbuhkan pribadi yang diharapkan. Ia juga berdampak pada proses pembelajaran dan kemampuan mengembangkan berbagai tujuannya melalui penguatan sikap, keterampilan, dan pengetahuan secara terintegrasi. Proses tersebut meliputi kegiatan: mengamati, menanya, mencoba, menalar, dan mengkomunikasikan. Dalam perjalanan kurikulum sekolah di Indonesia dan proses pembelajarannya, penguatan aspek kognitif dan ketrampilan masih dominan, sebaliknya penanaman sikap (spiritual dan sosial) masih kurang, padahal sikap ini akan menunjang kegiatan pembelajaran yang berorientasi pada penanaman karakter. Oleh karena kurikulum dan proses pembelajaran sebelum ini masih tampak berseberangan dan belum mengindikasikan pada proses pencapaian kompetensi pada aspek sikap, maka kurikulum sekolah yang diterapkan sekarang ini disesuaikan dengan kebutuhan tersebut. Sehingga mengakomodasi unsur-unsur kepribadian yang mencakup: keyakinan, nilai, dan perilaku secara menyeluruh.
\end{abstract}

Kata kunci: Pembelajaran, Kecakapan Berpikir, Pendekatan Ilmiah.

\section{PENDAHULUAN}

Dalam upaya meningkatkan kualitas pendidikan, pemerintah Indonesia terus berbenah dengan membekali peserta didik berbagai pengalaman belajar, sebagaimana yang tertuang dalam tujuan pendidikan nasional yang mengehendaki terintegrasinya sikap (afektif), pengetahuan (knowledge) dan ketrampilan (skill) secara utuh dalam pribadi peserta didik. Sikap akan tampak pada perubahan tingkah laku peserta didik, seperti timbulnya perhatian terhadap pelajaran di kelas, motivasi belajar, disiplin, menghormati guru dan sesama teman, dan lain-lain. Pengetahuan merupakan kemahiran intelektual yang ditunjukkan dengan 
kemampuan memecahkan masalah dan langkah-langkah berfikir untuk itu. Sedangkan ketrampilan merupakan kesanggupan untuk menerapkan pengetahuan sesuai dengan sikap yang dimilikinya. Ketrampilan dapat berbentuk gerakan anggota badan maupun kecakapan berfikir. Ketiga ranah kompetensi tersebut memiliki lintasan perolehan (proses psikologis) yang berbeda. Sikap diperoleh melalui aktivitas "menerima, menjalankan, menghargai, menghayati, dan mengamalkan". Pengetahuan diperoleh melalui aktivitas "mengingat, memahami, menerapkan, menganalisis, mengevaluasi, mencipta. Keterampilan diperoleh

melalui aktivitas "mengamati, menanya, mencoba, menalar, menyaji, dan mencipta”. Karaktersitik kompetensi beserta perbedaan lintasan perolehan turut serta mempengaruhi karakteristik standar proses. ${ }^{1}$

Kecakapan berpikir (thinking skills) sebagai bagian dari tujuan pendidikan nasional merupakan kemampuan dasar yang harus dimiliki peserta didik. Karena ia berangkat dari pemahaman bahwa belajar berfikir yang baik berarti belajar cara belajar yang efektif. Pembelajaran yang efektif akan menghasilkan sesuatu yang berkualitas. Disamping itu, tingkat kecakapan berpikir seseorang akan berpengaruh terhadap pola pikir, tingkah laku, dan menentukan bentuk pilihan hidupnya. Mengingat kehidupan manusia sebagian besar dipengaruhi oleh cara berpikir, maka peserta didik perlu diberi bekal dasar dan latihan-latihan cara berfikir yang benar. Kecakapan berpikir perlu terus dikembangkan sampai pada kemampuan megidentifikasi masalah, variable, dan memberi alternatif solusinya. Penyelesaian masalah secara kolaboratif juga dapat meningkatkan kemampuan kecakapan berpikir dan kecakapan sosial. ${ }^{2}$ McGregor tentang hal itu mengatakan bahwa "Problem solving appears to offer excellent potential for nurturing thinking skills. If the problems are approached collectively in small groups, than many sosial skills can also be encouraged and developed to enhance collaboration. $^{3}$

\footnotetext{
1 -----, Pearturan Menteri Pendidikan dan Kebudayaan Nomor 65 Tahun 2013, 3

2 Ahmadi, Menejemen Kurikulum Pendidikan Kecakapan Hidup, (Yogyakarta: Pustaka Ifada, 2013), 113.

${ }^{3}$ McGregor, Developing Thinking, Developing Learning, A Guide to Thinking Skills in Education, (England: McGraw Hill House, 2007), 44.
} 
Standar proses pembelajaran pada mulanya terbagi kepada tiga langkah kegiatan yaitu eksplorasi, elaborasi dan konfirmasi. Kemudian pada perubahan kurikulum tahun 2013 diubah menjadi lima langkah yaitu: mengamati, menanya, mencoba, mengasosiasi dan mengkomunikasi. Kelima langkah pembelajaran ini disebut dengan proses pembelajaran dengan menggunakan pendekatan ilmiah (scientific). Karena mengingat pentingnya kecakapan berpikir dalam proses pembelajaran dengan pendekatan tersebut, maka peneliti tertarik untuk meneliti bagaimana konsep kecakapan berpikir (thinking skills) dalam konteks pendekatan tersebut pada kurikulum sekolah di Indonesia. Apa hakikatnya kecakapan berfikir itu, bagaimana tahapannya dalam proses pembelajaran dengan pendekatan ilmiah dan apa kontribusinya dalam pengembangan kerikulum sekolah di Indonesia.

Jenis penelitian ini adalah kajian pustaka, artinya telaah yang dilaksanakan untuk memecahkan masalah penelitian bertumpu pada telaah kritis dan mendalam terhadap bahan-bahan pustaka yang relevan. Dalam hal ini bahan-bahan pustaka diberlakukan sebagai sumber ide untuk menggali pemikiran atau gagasan baru, sebagai bahan dasar untuk melakukan deduksi dari pengetahuan yang telah ada, sehingga kerangka teori baru dapat dikembangkan atau sebagai dasar pemecahan masalah. Untuk pengumpulan data menggunakan teknik dokumentasi, yaitu mengumpulkan data melalui peninggalan tertulis, berupa buku-buku teks dan berbagai produk undang-undang, terutama dalam kaitannya dengan kurikulum sekolah. Analisis data menggunakan teknik content analisis (analisis isi), yakni menarik kesimpulan melalui usaha menemukan karakteristik pesan, yang penyelesaiannya dilakukan secara objektif dan sistematis dengan cara membandingkan isi sebuah buku dengan buku lain dalam bidang kajian yang sama.

\section{Kecakapan berfikir sebagai pendekatan ilmiah}

Manusia merupakan makhluk ciptaan Allah swt yang paling sempurna, karena disamping memiliki struktur tubuh yang lengkap, ditambah lagi dengan pemberian akal, sehingga lengkaplah kesempurnaannya dibanding makhlukmakhluk lainnya. Dengan akalnya manusia dapat mengatur dan mengerahkan 
segala sesuatu. Perubahan-perubahan yang terjadi pada manusia selalu menggunakan potensi akal yang disebut berfikir. Agar manusia mampu melakukan perubahan dengan cepat dan tepat maka diperlukan sebuah kecakapan berfikir. Karena itulah kecakapan berpikir (thinking skills) merupakan faktor esensial dalam menentukan arah, tindakan, maupun keputusan yang diambil manusia. Untuk itu, belajar cara berpikir yang baik merupakan faktor yang mendukung dalam menentukan arah, tindakan, maupun keputusan yang benar.

Berpikir adalah proses mental seseorang yang lebih dari sekedar mengingat dan memahami. Kegiatan mengingat dan memahami lebih bersifat pasif dari pada kegiatan berpikir. ${ }^{4}$ Menurut Plato sebagaimana dikutip Kowiah bahwa berpikir adalah berbicara dalam hati. ${ }^{5}$ Artinya bahwa berpikir merupakan proses kejiwaan yang menghubung-hubungkan atau membanding-bandingkan antara situasi, fakta, ide atau kejadian dengan fakta, ide atau kejadian lainnya. Dengan demikian kecakapan berpikir adalah situasi yang membutuhkan kemahiran seseorang dengan memanfaatkan pengetahuan, pemahaman, atau keterampilan yang sudah dimilikinya melalui proses mental sehingga ia mampu menemukan sesuatu yang tepat dan sesuai sebagai jalan keluar terhadap masalah yang dihadapinya.

Kecakapan berpikir memiliki peran utama dalam memainkan proses pengetahuan di berbagai ruang, waktu, dan tempat. Tanpa kehadirannya pengetahuan yang tercipta kurang bermakna. Dari sini ia merupakan proses yang mendorong, membawa perubahan, dan menghasilkan sesuatu yang baru. Dalam konteks pembelajaran kecakapan berpikir harus terintegrasi dalam pendekatan ilmiah. Pembelajaran dengan pendekatan ilmiah merupakan proses pembelajaran yang dirancang sedemikian rupa, agar peserta didik secara aktif membangun konsep, hukum atau prinsip melalui tahapan-tahapan: mengamati (untuk mengidentifikasi atau menemukan masalah), merumuskan masalah, mengajukan atau merumuskan hipotesis, mengumpulkan data dengan berbagai teknik,

${ }^{4}$ Tri Joko, "Peningkatan Kemampuan Berpikir Kritis Melalui Model Pembelajaran Children Learning In Science (CLIS) pada Siswa Kelas VIII SMP Negeri 1 Mirit Tahun Pelajaran 2012/2013" Jurnal Radiasi, Volume 3 Nomor 2, 2012, 113.

5 Kowiyah, "Kemampuan Berpikir Kritis", Jurnal Pendidikan Dasar, Volume 3 Nomor 5, (Desember 2012), 175. 
menganalisis data, menarik kesimpulan dan mengkomunikasikan konsep, hukum atau prinsip yang ditemukan.

Pendekatan ilmiah dimaksudkan untuk memberikan pemahaman kepada peserta didik dalam mengenal, memahami berbagai materi menggunakan pendekatan ilmiah, bahwa informasi bisa berasal dari mana saja, kapan saja, tidak bergantung pada informasi searah dari pendidik. Oleh karena itu kondisi pembelajaran yang diharapkan tercipta diarahkan untuk mendorong peserta didik dalam mencari tahu dari berbagai sumber melalui observasi, bukan hanya diberi tahu. Untuk itu tujuan pembelajaran dengan pendekatan ini didasarkan pada keunggulan pendekatan tersebut, antara lain: (1) meningkatkan kemampuan intelek, khususnya kemampuan berpikir tingkat tinggi, (2) untuk membentuk kemampuan siswa dalam menyelesaikan suatu masalah secara sistematik, (3) terciptanya kondisi pembelajaran dimana peserta didik merasa bahwa belajar itu merupakan suatu kebutuhan, (4) diperolehnya hasil belajar yang tinggi, (5) untuk melatih peserta didik dalam mengkomunikasikan ide-ide dan (6) untuk mengembangkan karakter peserta didik. ${ }^{6}$

Dengan demikian konteks pembelajaran dalam pendekatan ilmiah bertujuan untuk meningkatkan kemampuan peserta didik, khususnya kemampuan berpikir tingkat tinggi, membentuk keterampilan untuk menyelesaikan suatu permasalahan dengan menggunakan langkah-langkah ilmiah, meningkatkan keinginannya untuk belajar, miningkatkan hasil belajar, melatih mengkomunikasikan ide serta pendapatnya secara lisan maupun tulisan dan mengembangkan karakternya. Pendekatan ilmiah menuntut peserta didik untuk mampu memecahkan masalah secara mandiri, mentransformasikan informasi secara luas, menemukan kembali informasi baru, dan melakukan pengembangan informasi menurut kemampuan sesuai dengan lingkungan sekitarnya. Pendekatan ilmiah mengedepankan cara memperoleh pengetahuan melalui inkuiri. Inkuiri adalah sebuah strategi yang dirancang untuk meningkatkan kelancaran dan ketepatan peserta didik dalam memecahkan masalah, membangun konsep dan hipotesis, dan pengujian hipotesis.

\footnotetext{
${ }^{6}$ A. Machin, "Implementasi Pendekatan Saintifik, Penanaman Karakter dan Konservasi pada Pembelajaran Materi Pertumbuhan”, Jurnal Pendidikan IPA Indonesia,Volume 3 Nomor 1, (2014), 28.
} 
Strategi inkuiri dapat mengembangkan kecakapan hidup peserta didik dalam bekerjasama, merumuskan masalah, menganalisis data dan membuat kesimpulan. ${ }^{7}$

\section{Kurikulum Sekolah dan Proses Pembelajaran}

Bagi sebuah sekolah kurikulum merupakan seperangkat program yang akan digunakannya untuk mencapai tujuannya. Kurikulum harus disusun dengan menyeimbangkan berbagai kepentingan, baik mencakup kepentingan individu peserta didik, orangtua, masyarakat, bangsa dan Negara. Kurikulum harus mampu menyelesaikan persoalan yang menimpa generasi muda dan anak bangsa, termasuk persoalan kekerasan dan demoralisasi. Beberapa ahli pendidikan dan tokoh masyarakat menyatakan bahwa salah satu akar masalahnya adalah implementasi kurikulum yang belum mengajarkan proses berpikir yang baik serta keterkungkungan peserta didik di ruang belajarnya dengan kegiatan yang kurang menantang peserta didik. Oleh karena itu, kurikulum perlu direorientasi dan direorganisasi agar dapat menjawab kebutuhan ini. Di Indonesia telah berulangulang dilakukan reorganisasi kurikulum, mulai tahun 1975 dengan Prosedur Pengembangan Sistem Instruksional (PPSI), tahun 1984 disempurnakan dengan system CBSA (Cara Belajar Siswa Aktif), Tahun 1994 dengan penguatan pendekatan Ketrampilan Proses, Tahun 2004 dengan Kurikulum Berbasis Kompetensi (KBK) yang kemudian disempurnakan pada Tahun 2013.

Kurikulum berbasis kompetensi tersebut mencakup tiga aspek (sikap, pengetahuan, dan keterampilan) yang hendak ditingkatkan dan diseimbangkan dengan sistem yang ada melalui penguatan sikap, keterampilan, dan pengetahuan yang terintegrasi. Diharapkan kurikulum ini dapat menghasilkan generasi muda yang produktif, kreatif, inovatif, dan afektif di masa depan. ${ }^{8}$ Dengan demikian kecakapan berpikir sangat diperlukan dalam konteks pendekatan pembelajaran, karena merupakan proses berpikir ilmiah yang bertujuan menumbuhkan pribadi yang diharapkan.

\footnotetext{
${ }^{7}$ Ibid., 33.

${ }^{8}$ Andang, Kebijakan Kurikulum (Malang: UMM Press, 2014), 151
} 
Kecakapan berpikir merupakan suatu tindakan mental untuk memperoleh pengetahuan, pemahaman dan keterampilan agar mampu menemukan jalan keluar dan keputusan secara deduktif, induktif dan evaluatif sesuai dengan tahapannya. ${ }^{9}$ Dalam konteks ini proses atau tindakan mental sebagaimama taksonomi Bloom mencakup kegiatan: mengingat, memahami, menerapkan, menganalisis, mengevaluasi, dan mencipta. ${ }^{10}$ Taksonomi proses berpikir inilah yang kemudian menjadi salah satu rujukan dalam pengembangan kurikulum sekolah terkait dengan tujuan pendidikan dalam aspek pengetahuan.

Selanjutnya terkait dengan esensi kecakapan berpikir dalam pembelajaran merujuk pada pandangan bahwa pembelajaran pada dasarnya merupakan proses berpikir ilmiah. Untuk itu proses berpikir ilmiah dianggap penting untuk ditumbuhkan dan dibiasakan pada peresta didik. Dalam hal ini pendekatan ilmiah dipandang paling sesuai dalam pengembangan sikap, keterampilan, dan pengetahuan peserta didik. Dalam pendekatan atau proses kerja ilmiah, para ilmuwan lebih mengedepankan penalaran induktif (inductive reasoning) daripada penalaran deduktif (deductive reasoning). Penalaran deduktif dilakukan dengan mengamati fenomena umum untuk menarik kesimpulan yang spesifik.

Menurut Piaget, sebenarnya belajar bukan suatu yang diturunkan oleh sebuah kepentingan, melainkan sesuatu yang berasal dari dalam diri anak sendiri. Belajar merupakan sebuah proses penyelidikan dan penemuan spontan. ${ }^{11}$ Dalam perspektif kognitif belajar merupakan suatu proses internal yang tidak dapat diamati langsung. Perubahan tingkah laku seseorang tidak nampak, sesungguhnya hanyalah refleksi dari perubahan internalisasi persepsi dirinya terhadap sesuatu yang sedang dihadapi dan dipikirkannya. ${ }^{12}$ Menurut teori ini ilmu pengetahuan dibangun dalam diri individu melalui proses interaksi yang berkesinambungan dengan lingkungan. Teori belajar Vygotsky menyatakan bahwa pembelajaran

\footnotetext{
${ }^{9}$ Kowiyah, “ Kemampuan Berpikir..., 176.

${ }^{10}$ David R. Krathwohl, THEORY INTO PRACTICE”, Volume 41, Number 4, Autumn

${ }^{11}$ William Crain, Teori Perkembangan, Konsep dan Aplikasi, terj.Yudi Santosa (Yogyakarta: Pustaka Pelajar, 2007), 208.

${ }^{12}$ Hamzah B Uno, Orientasi Baru dalam Psikologi pembelajaran (Jakarta: Bumi Aksara,
} 2002, 212. 2006), 52 . 
terjadi apabila siswa bekerja atau belajar menangani tugas-tugas yang belum dipelajari, tetapi tugas-tugas tersebut masih berada dalam jangkauan kemampuan (Proximal development zone) melalui bimbingan orang dewasa atau teman sebaya yang lebih kompeten ${ }^{13}$.

Lebih lanjut proses pembelajaran harus membantu dan memungkinkan peserta didik aktif mengkonstruksi pengetahuanya sendiri. Menurut Bruner dalam Carin \& Snd menyebutkan ada 4 hal pokok yang berkaitan dengan teori belajar penemuan: (1) individu hanya belajar dan mengembangkan pikirannya apabila ia menggunakan pikirannya; (2) dengan melakukan proses kognitif dalam proses penemuan, siswa akan memperoleh sensasi dan kepuasan intelektual; (3) seseorang dapat mempelajari teknik-teknik dalam melakukan penemuan dan (4) dengan melakukan penemuan, retensi ingatan siswa akan menguat. ${ }^{14}$ Dari 4 hal pokok tersebut bersesuaian dengan proses kognitif yang diperlukan dalam pembelajaran berbasis kreativitas dengan pendekatan ilmiah.

Dari sini dapat dipahami bahwa esensi kecakapan berpikir dalam pembelajaran mengarah pada optimalisasi rasio dalam mengkonstruksi pengetahuan, pemahaman dan keterampilan melalui proses berpikir ilmiah. Karena itu, 5M (mengamati, menanya, mencoba, menalar, dan mengkomunikasikan) sebagaimana tercantum dalam pendekatan ilmiah bukanlah prosedur atau langkah-langkah maupun pendekatan pembelajaran, melainkan merupakan proses berpikir ilmiah yang perlu dilatih secara terus menerus melalui pembelajaran agar siswa mampu berpikir saintifik.

Pendekatan Ilmiah diyakini sebagai titian emas perkembangan dan pengembangan sikap, keterampilan, dan pengetahuan peserta didik. $^{15}$ Pembelajaran dengan pendekatan ilmiah menekankan pada pentingnya kolaborasi dan kerja sama diantara peserta didik dalam menyelesaikan setiap permasalahan dalam pembelajaran. Oleh karena itu, guru sedapat mungkin menciptakan

13 Sajidan, Pembelajaran Biologi dengan Pendekatan Saintifik pada Implementasi Kurikulum 2013, Seminar Nasional XI Pendidikan Biologi FKIP UNS, 21.

${ }^{14}$ Ibid., 21.

${ }^{15}$ Abdul Majid dan Chaerul Rochman, Pendekatan Ilmiah dalam Implementasi Kurkulum 2013 (Bandung: PT Remaja Rosdakarya, 2015), 71. 
pembelajaran selain dengan tetap mengacu pada standar proses dimana pembelajaranya diciptakan dengan suasana yang memuat eksplorasi, elaborasi, dan konfirmasi, juga mengedepankan kondisi peserta didik yang berprilaku ilmiah dengan bersama-sama diajak mengamati, menanya, menalar, merumuskan, menyimpulkan dan mengkomunikasikan.

Pembelajaran dengan pendekatan ilmiah merupakan pebelajaran yang dirancang agar peserta didik secara aktif mampu mengkonstruk konsep, hukum, atau prinsip melalui kegiatan mengamati (untuk mengindentifikasi hal-hal yang ingin diketahui), merumuskan pertanyaan (dan merumuskan hipotesis), mencoba/mengumpulkan data (informasi) dengan berbagai teknik, mengasosiasi/menganalisis/mengolah data (informasi) dan menarik kesimpulan serta mengkomunikasikan kesimpulan untuk memperoleh pengetahuan, keteramplan dan sikap. Dengan menumbuhkan kemampuan seperti itu dan terus menerus melatih dan membiasakannya akan mendorong peserta didik menjadi pembelajar sepanjang hayat dan bersikap ilmiah dalam kehidupan.

Pendekatan pembelajaran dapat diartikan sebagai titik tolak atau sudut pandang kita terhadap proses pembelajaran yang merujuk pada pandangan tentang terjadinya suatu proses yang sifatnya masih sangat umum, di dalamnya mewadahi, menginsiprasi, menguatkan, dan melatari metode pembelajaran dengan cakupan teori tertentu. ${ }^{16}$ Richard and Rodgers dalam Muhammad Yaumi menjelaskan " $\mathrm{An}$ approach is a set of correlative assumption dealing with the nature of language teaching and learning. An approach is axiomatic which describes nature of the subject matter to be taught". ${ }^{17}$ Pendekatan merupakan serangkaian asumsi korelatif yang berhubungan dengan hakikat pembelajaran. Pendekatan adalah suatu aksiomatik yang menggambarkan sifat dari mata pelajaran yang diajarkan.

Pendekatan ilmiah pertama kali diperkenalkan di dunia pendidikan Amerika pada akhir abad ke-19, sebagai penekanan pada penggunaan metode laboratorium formalistik yang mengarah pada fakta-fakta ilmiah. Pendekatan ini memiliki karakteristik "doing science". Pendekatan ini memudahkan guru untuk

\footnotetext{
${ }^{16}$ Hamruni, Strategi Pembelajaran (Yogyakarta: Insan Madani, 2012), 6.

${ }^{17}$ Muhammad Yaumi, Prinsip-prinsip Desain Pembelajaran diesuakan dengan Kurikulum 2013 (Jakarta: Kencana Prenadamedia Group, 2014), 231.
} 
memperbaiki proses pembelajaran, yang prosesnya berupa langkah-langkah atau tahapan-tahapan yang memuat petunjuk kepada peserta didik agar melaksanakan kegiatan. ${ }^{18}$ Model inilah yang menjadi dasar pengembangan kurikulum sekolah di Indonesia saat ini. Kemendikbud menyajikan konsep tentang pendekatan ilmiah ini sebagai suatu pendekatan pembelajaran yang di dalamnya terdapat kegiatan mengamati, menanya, mencoba, mengasosiasikan, dan mengomunikasikan ${ }^{19}$.

Daryanto mengemukakan bahwa pembelajaran dengan menggunakan pendekatan ilmiah adalah proses pembelajaran yang dirancang sedemikian rupa agar peserta didik secara aktif mengkonstruksi konsep, hukum, atau prinsip dengan melibatkan keterampilan proses seperti mengamati, menanya, mengumpulkan informasi, menalar, mencoba, menarik kesimpulan, dan mengomunikasikan. ${ }^{20}$ Sedangkan Meliawati mengemukakan bahwa pendekatan saintifik adalah salah satu pendekatan dalam melaksanakan pembelajaran dengan menggunakan pendekatan ilmiah dan inkuiri. ${ }^{21}$ Dengan demikian proses pembelajaran harus dilaksanakan dengan dipandu nilai-nilai, prinsip-prinsip, atau kriteria ilmiah. Proses pembelajaran disebut ilmiah jika memenuhi kriteria sebagai berikut:

1. Substansi atau materi pembelajaran berbasis pada fakta atau fenomena yang dapat dijelaskan dengan logika atau penalaran tertentu, bukan sebatas perkiraan, khayalan, legenda, atau dongeng semata.

2. Penjelasan guru, respons peserta didik, dan interaksi antara guru dan peserta didik terbebas dari prasangka, pemikiran subjektif, atau penalaran yang menyimpang dari alur berpikir logis.

${ }^{18}$ Varelas, $\mathrm{M}$ and Ford M, The Scientific Method and Scientific Inquiry: Tensions in Teaching and learning (USA: Wiley InterScience, 2009), 31.

19 Nur Fajar Arief, Konsep dan Contoh Pendekatan Scientific dalam Pembeajaran (Jakarta:Tim Narasumber TOT Kurikulum 2013 Kemenag RI)

20 Daryanto, Penelitian Tindakan Kelas dan Penelitian Tindakan Sekolah Beserta Contoh-contohnya (Yogyakarta: Gava Media, 2011), 51.

${ }^{21}$ Ni Wyn. Meliawati dkk, “Analisis Penerapan Pendekatan Saintifik Terhadap Dalam Pembelajaran Berdasarkan Kurikulum 2013”, e-Journal PGSD Universitas Pendidikan Ganesha Jurusan PGSD Volume 3, Nomor 1, (2015). 
3. Mendorong dan menginspirasi pserta didik berpikir secara kritis, analitis, dan tepat dalam mengidentifikasi, memahami, memecahkan masalah dan mengaplikasikan substansi atau materi pembelajaran.

4. Mendorong dan menginspirasi peserta didik mampu berpikir secara hipotesis dalam melihat perbedaan, kesamaan, dan tautan satu sama lain dari substansi atau materi pembelajaran.

5. Mendorong dan menginspirasi peserta didik mampu memahami, menerapkan, dan mengembangkan pola berpikir yang rasional dan objektif dalam merespons substansi atau materi pembelajaran.

6. Berbasis pada konsep, teori dan fakta empiris yang dapat dipertanggung jawabkan. $^{22}$

Pendekatan ilmiah bertujuan untuk memberikan pemahaman kepada peserta didik dalam mengenal dan memahami berbagai materi pelajaran. Informasi materi pelajaran bisa berasal dari mana saja, kapan saja, tidak bergantung pada informasi searah dari guru. Oleh karena itu kondisi pembelajaran yang diharapkan tercipta diarahkan untuk mendorong peserta didik dalam mencari tahu dari berbagai sumber melalui observasi, dan bukan hanya diberi tahu. Karena itu pendekatan ini memiliki beberapa keunggulan, antara lain: (1) meningkatkan kemampuan intelek, khususnya kemampuan berpikir tingkat tinggi, (2) membentuk peserta didik mampu menyelesaikan berbagai masalah secara sistematik, (3) terciptanya kondisi pembelajaran dimana peserta didik merasa bahwa belajar itu merupakan suatu kebutuhan, (4) diperolehnya hasil belajar yang tinggi, (5) untuk melatih siswa dalam mengomunikasikan ide-ide dan (6) untuk mengembangkan karakter siswa. $^{23}$

Proses pembelajaran dengan menggunakan pendekatan ilmiah bertujuan untuk meningkatkan kemampuan peserta didik, khususnya kemampuan berpikir tingkat tinggi, membentuk keterampilan peserta didik menyelesaikan suatu

\footnotetext{
2014), 194

${ }^{22}$ Abdul Majid, Pembelajaran Tematik Terpadu ( Bandung: PT Remaja Rosdakarya,

${ }^{23}$ A. Machin, "Implementasi Pendekatan Saintifik, Penanaman Karakter dan Konservasi pada Pembelajaran Materi Pertumbuhan”, Jurnal Pendidikan IPA Indonesia,Volume 3 Nomor 1, (2014), 28.
} 
permasalahan dengan menggunakan langkah-langkah ilmiah, meningkatkan keinginannya untuk belajar, miningkatkan hasil belajarnya, melatih mengomunikasikan ide serta pendapatnya secara lisan maupun tulisan dan mengembangkan karakter. Pendekatan ini menuntut peserta didik dapat menemukan pemecahan masalah yang dihadapinya, mentransformasikannya untuk menemukan informasi baru, serta melakukan pengembangan sesuai dengan situasi dan kondisi lingkungan sekitarnya. Pendekatan ini juga terkait dengan penggunaan strategi inkuiri untuk mengembangkan kecepatan dan ketepatannya dalam memecahkan suatu masalah, membangun konsep dan pengujian hipotesis.

Dalam Forum Kebijakan Ilmiah yang diterbitkan di Amerika pada tahun 2004, sebagaimana dikutip Wikipedia, dinyatakan bahwa pembelajaran ilmiah mencakup strstegi pembelajaran yang mengintegrasikan peserta didik aktif melalui proses berpikir dengan menggunakan metode yang teruji secara ilmiah sehingga dapat membedakan kemampuan siswa yang bervariasi. Penerapan metode ilmiah membantu guru dalam mengidentifikasi perbedaan kemampuan peserta didik. $^{24}$

Bahwa standar kompetensi lulusan sebagaimana yang dirumuskan pada kurikulum sekolah saat ini telah mencakup sasaran pembelajaran yang mengembangkan ranah sikap, pengetahuan, dan keterampilan yang dielaborasi untuk setiap satuan pendidikan. Ketiga ranah kompetensi tersebut memiliki lintasan perolehan yang berbeda. Sikap diperoleh melalui aktivitas "menerima, menjalankan, menghargai, menghayati, dan mengamalkan". Pengetahuan diperoleh melalui aktivitas: mengingat, memahami, menerapkan, menganalisis, mengevaluasi, dan mencipta. Keterampilan diperoleh melalui aktivitas "mengamati, menanya, mencoba, menalar, menyaji, dan mencipta". ${ }^{25}$ Pendekatan ilmiah dalam pembelajaran tersebut meliputi: mengamati, menanya, mencoba, menalar, membentuk jejaring untuk semua mata pelajaran. ${ }^{26}$

\footnotetext{
${ }^{24}$ Ibid., 71.

${ }^{25}$ Andang, Kebijakan ...., 151

${ }^{26}$ Kementrian Pendidikan dan Kebudayaan, Konsep dan Implementasi Kurikulum 2013 (Jakarta: Kemendikbud, 2014)
} 
Tahapan kecakapan berfikir dalam pembelajaran.

Kegiatan pembelajaran menekankan pentingnya keaktifan peserta didik untuk mencapai kompetensinya. Dengan menekankan keaktifan mengolah bahan ajar, aktif bertanya, kritis mencerna pesan, maka peserta didik akan dapat menguasai kompetensi secara baik. Kegiatan pembelajaran seperti itulah yang disebut suatu proses ilmiah. Karena itu, kurikulum sekolah di Indonesia dewasa ini mengamanatkan bentuk pembelajaran melalui pendekatan ilmiah. Konsep tentang pendekatan ilmiah dalam sebuah pembelajaran melalui tahapan tahapan kegiatan yang disebut 5M, yaitu: mengamati, menanya, mencoba, mengasosiasikan, dan mengomunikasikan ${ }^{27}$. Sudah barang tentu implementasinya melalui kecakapan berpikir yang harus di latih secara terus menerus dengan tahapan sebagai berikut:

1. Mengamati (Observing)

Mengamati atau melakukan observasi yaitu melakukan pengamatan secara mendalam terhadap fakta atau fenomena yang berada di sekitarnya. Mengamati merupakan salah satu kecakapan dasar dalam menggali dan menemukan informasi (information searching). Kecakapan dasar lainnya adalah membaca dan berhitung. Kegiatan membaca bukan hanya suatu kegiatan membunyikan (melafalkan) huruf, kata atau kalimat, tapi mampu memaknainya. Menghitung juga demikian, bukan hanya belajar secara mekanistik menerapkan kalkulasi angka, tetapi mengartikan apa informasi dalam perhitungan tersebut.

Ahmadi mengutip pendapat McGregor yang memberikan ilustrasi tentang kategori kecakapan berpikir yaitu: (1) Information processing skills, (2) Reasoning skills, (3) Inquiry, (4) Creativity, (5) Evaluation. ${ }^{28}$ Dalam aplikasinya mengamati atau melakukan observasi termasuk dalam kategori kecakapan memproses informasi (information processing skills). Kecakapan ini mencakup: kecakapan menemukan informasi yang relevan, kecakapan

\footnotetext{
${ }^{27}$ Nur Fajar Arief, "Konsep dan Contoh Pendekatan Scientific dalam Pembeajaran" dalam makalah: TOT Kurikulum 2013 Kemenag RI.

${ }^{28}$ Ahmadi, Menejemen Kurikulum ..., 115.
} 
memilih, mengklasifikasi, menyusun urutan informasi, kecakapan membandingkan atau mencocokan informasi, kecakapan mengidentifikasi, dan menganalisis informasi.

Mengamati mengutamakan kebermaknaan proses pembelajaran (meaningfull learning). Tahapan ini bermanfaat bagi pemenuhan rasa ingin tahu peserta didik, sehingga proses pembelajaran memiliki kebermaknaan yang tinggi. Dengan melakukan observasi peserta didik menemukan fakta bahwa ada hubungan antara objek yang dianalisis dengan materi pembelajaran yang digunakan oleh guru. $^{29}$

2. Menanya (Questioning).

Kegiatan pembelajaran ini dilakukan dengan cara mengajukan pertanyaan untuk memperoleh informasi hal-hal yang belum bisa dipahami dari apa yang diamati, atau pertanyaan untuk mendapatkan informasi tambahan tentang apa yang diamati (dimulai dari pertanyaan faktual sampai ke pertanyaan yang bersifat hipotetik). ${ }^{30}$ Dalam pelaksanaannya kegiatan ini membutuhkan kecakapan tentang cara membuat pertanyaan meliputi: bentuk pertanyaan, isi pertanyaan, rumusan pertanyaan, dampak kegiatan dari pertanyaan yang diajukan, gambaran hasil yang diperoleh atas jawaban dari pertanyaan, yang pada akhirnya memerlukan sebuah kecakapan berpikir.

3. Mencoba (Experiment)

Untuk memperoleh hasil belajar yang nyata atau otentik, peserta didik harus memperoleh pengalaman langsung, karena itu perlu melakukan percobaan, sesuai dengan tema dan materi yang direncanakan. Disini peserta didik memerlukan kecakapan berfikir untuk memproses pengetahuan yang dipelajari dan mengelaborasikannya dengan lingkungan sekitar dengan menggunakan pendekatan ilmiah untuk memecahkan masalah-masalah yang dihadapinya sehari-hari. ${ }^{31}$ Dari sini lahirlah kreatifitas dalam bentuk

${ }^{29}$ Rahmatiah, "Pendekatan Saintifik sebagai Solusi dalam Pembelajaran Biologi” eBuletin (Makasar: Media Pendidikan dan LPMP Sulawesi Selatan, Edisi bulan Mei 2015), 7.

${ }^{30}$ Ibid,. 7.

${ }^{31}$ Ibid., 9. 
munculnya ide-ide baru dan mengembangkannya melalui berbagai hipotesa dan lahirlah sebuah inovasi.

4. Mengasosiasikan/mengolah informasi (Anaylyze)

Mengasosiasikan/menalar adalah proses berpikir yang logis dan sistematis atas fakta-fakta empiris yang dapat diobservasi untuk memperoleh simpulan berupa pengetahuan. Aktivitas pembelajaran yang dapat meningkatkan daya nalar peserta didik dapat dilakukan dengan cara memberi ulasan pada opini atau pilihannya, menyimpulkan, membuat deduksi dan membuat keputusan berbasis informasi, dengan menggunakan bahasa yang logis.

5. Mengkomunikasikan (Communicating)

Kegiatan mengkomunikasikan dalam pembelajaran dilakukan dengan cara menyampaikan hasil pengamatan dan penarikan kesimpulan berdasarkan hasil analisis peserta didik, secara lisan atau tertulis, atau dengan menggunakan media lainnya. ${ }^{32}$

Dari berbagai tahapan kecakapan berpikir sebagaimana uraian di atas telah jelas bahwa proses berpikir ilmiah akan berdampak besar pada proses pembelajaran serta mampu menumbuhkan dan mengembangkan berbagai tujuan pembelajaran, antara lain menumbuhkan sosok pribadi yang produktif, kreatif dan inovatif melalui penguatan sikap, keterampilan, dan pengetahuan yang terintegrasi. Namun demikian jika merujuk pada proses berpikir sebagaimana yang termuat dalam kurikulum sekolah, mencakup kegiatan mengamati, menanya, mencoba, menalar, dan mengkomunikasikan, maka tampak bahwa sebenarnya dalam proses berpikir ini belum mencakup kegiatan memutuskan nilai-nilai dari suatu informasi dan ide. Karena proses berpikir yang baik akan mencakup kegiatan analisis dan evaluasi. Evaluasi berguna untuk menentukan output dan tindakan yang akan dilakukan. Sebagaimana dikemukakan oleh Ahmadi bahwa proses evaluasi mencakup kegiatan: "mengembangkan kriteria evaluasi, menerapkan kriteria evaluasi, dan memutuskan nilai-nilai informasi dan

\footnotetext{
32 ..., Peraturan Menteri Pendidikan dan Kebudayaan Republik Indonesia No. 81A Tahun 2013 tentang Implementasi Kurikulum
} 
ide". ${ }^{33}$ Dalam tahapan proses berpikir diatas, menurut peneliti ada yang terputus, karena taksonomi pembelajaran masih didominasi dengan taksonomi model Anderson dan keterampilan berinovasinya Jeff Dyer, dengan indikasi belum terintegrasinya nilai dalam pembinaan pribadi yang utuh (kamil) pada tahapan berpikir ilmiah.

Sementara itu jika diperhatikan baik dalam proses berpikir ilmiah maupun aspek keterampilan dalam kurikulum sekolah yang di dalamnya mencakup kegiatan mengamati, menanya, mencoba, menalar, dan mengkomunikasikan, belum mengindikasikan pada proses pencapaian kompetensi pada aspek sikap. Hal ini tampak dari belum adanya unsur-unsur kepribadian yang mencakup keyakinan, nilai, dan prilaku pada proses berpikir ilmah ini. Dengan kata lain proses berpikir pada pendekatan ilmiah dalam kurikulum sekolah masih belum mengindikasikan ketercapaian nilai dalam tahapan berpikirnya.

\section{Kontribusi Kecakapan berfikir dalam kurikulum sekolah di Indonesia.}

Kontribusi kecakapan berpikir dalam pendekatan pembelajaran pada kurikulum sekolah dilihat dari tujuannya adalah untuk mempersiapkan manusia Indonesia agar memiliki kemampuan hidup sebagai pribadi dan warga negara yang beriman, produktif, kreatif, inovatif, dan afektif. Sedangkan dilihat dalam prosesnya yang mencakup kegiatan mengamati, menanya, mencoba, menalar, dan mengkomunikasikan, untuk mengembangkan berbagai keterampilan seperti kecakapan memproses informasi, kecakapan inquiri, kecakapan bepikir kreatif dan kecakapan mengevaluasi. Dengan berbagai kecakapan berpikir tersebut, akhirnya akan berdampak pada pencapaian kecakapan akademik, keterampilan berpikir kritis, keterampilan berkomunikasi, keterampilan melakukan kerja sama dan penyelidikan serta perilaku berkarakter, karena pengalaman belajar yang diberikan dapat memenuhi tujuan pendidikan dan bermanfaat bagi pemecahan masalah dan kehidupan nyata.

\footnotetext{
${ }^{33}$ Ahmadi, Menejemen Kurikulum ..., 115.
} 
Bahwa kecakapan berpikir sebagai pendekatan dalam konteks pembelajaran pada kurikulum sekolah di Indonesia masih belum sepenuhnya mengembangkan berbagai kompetensi yang harus dimiliki peserta didik. Proses berpikir ilmiah masih terlepas dari proses pembentukan nilai, dan lebih condong pada pengembangan kompetensi kognitif dan ketrampilan. Sedangkan kompetensi sikap (spiritual dan sosial) kurang diutamakan, padahal kompetensi ini berhubungan erat dengan usaha penanaman karakter peserta didik. Dari sini terlihat betapa pentingnya kecakapan berpikir dalam pembelajaran, karena ia merupakan proses berpikir ilmiah yang diyakini mampu menumbuhkan dan mengembangkan berbagai esensi tujuan pendidikan.

Kedepan proses kecakapan berpikir harus dipandang sebagai kemampuan atau proses berpikir yang harus selalu ditumbuhkan dan dibiasakan pada peserta didik agar mereka terbiasa berpikir ilmiah. Menumbuhkan kemampuan itu tentunya harus dilakukan secara terus menurus, dilatih dan dibiasakan, sehingga mendorong peserta didik menjadi pembelajar sepanjang hayat dan bersikap ilmiah dalam kehidupan. Kecakapan berpikir yang dilatihkan secara terus menerus akan menjadi kebiasaan, sehingga ketika peserta didik menghadapi suatu masalah, ia dapat mengambil keputusan secara cepat, tepat, efektif dan efisien. Di masa datang keberhasilan seseorang dalam pendidikan bukan dari tingginya tingkat pendidikan yang diikuti, akan tetapi dari kecakapan diri dalam memecahkan masalah dalam kehidupannya..

Bahwa pola pikir seseorang akan mempengaruhi keputusan yang ditetapkannya. Keputusan tersebut berupa sebuah tindakan yang memerlukan tokoh panutan. Untuk itu pendidik sebagai pihak eksternal yang mempunyai pengaruh langsung kepada peserta didik, harus mampu mengkondisikan agar anak dapat berpikir kritis, bersikap dan bertindak ilmiah. Memang pengembangan keterampilan berpikir kritis di Indonesia masih memiliki beberapa kendala, salah satunya adalah adanya dominasi pendidik dalam proses pembelajaran sehingga 
tidak memberi akses pada peserta didik untuk berkembang secara mandiri melalui penemuan dari hasil proses berpikirnya. ${ }^{34}$

\section{Penutup}

Perubahan-perubahan yang terjadi pada manusia selalu menggunakan potensi akal yang disebut berfikir. Agar manusia mampu melakukan perubahan dengan cepat dan tepat maka diperlukan sebuah kecakapan berfikir. Karena itulah kecakapan berpikir merupakan faktor esensial dalam menentukan arah, tindakan, maupun keputusan yang diambil manusia. Untuk itu, belajar cara berpikir yang baik merupakan faktor yang mendukung dalam menentukan arah, tindakan, maupun keputusan yang benar.

Kecakapan berpikir merupakan proses berpikir ilmiah, karena itu penting untuk ditumbuhkan dan dibiasakan pada peresta didik. Dalam hal ini pendekatan ilmiah dipandang paling sesuai untuk pengembangan sikap, keterampilan, dan pengetahuan peserta didik. Kegiatan pembelajaran menekankan pentingnya kecakapan peserta didik untuk mencapai kompetensinya. Dengan menekankan kecakapan mengolah bahan ajar, kecakapan bertanya, kritis mencerna pesan, maka peserta didik akan dapat menguasai kompetensi secara baik. Pendekatan pembelajaran seperti itulah yang disebut suatu proses ilmiah. Karena itu, kurikulum sekolah di Indonesia dewasa ini mengamanatkan bentuk pembelajaran melalui pendekatan ilmiah. Konsep tentang pendekatan ilmiah dalam sebuah pembelajaran melalui tahapan tahapan kegiatan yang disebut 5M, yaitu: mengamati, menanya, mencoba, mengasosiasikan, dan mengomunikasikan.

Sampai saat ini kurikulum sekolah di Indonesia masih belum sepenuhnya mengembangkan pendekatan kecakapan berpikir dalam proses pembelajaran secara menyeluruh terhadap ketiga kompetensi yang ingin dicapai. Lebih condong pada pengembangan kompetensi kognitif dan ketrampilan, kurang mengembangkan kompetensi sikap. Padahal kompetensi sikap (spiritual dan

\footnotetext{
${ }^{34}$ Nyoman Paksa Adi Gama, "Pengaruh Implementasi Pendekatan Saintifik dengan Seting Inkuiri dalam Pembelajaran IPA terhadap Keterampilan Proses dan Hasil Belajar Siswa Kelas VII Smp Negeri 1 Singaraja".t.t.
} 
sosial) pada seluruh aktivitas pembelajaran sangat penting dalam rangka penanaman karakter peserta didik. Dari hasil penelitian ini menunjukkan betapa pentingnya pendekatan kecakapan berfikir dalam pembelajaran, karena ia merupakan proses berpikir ilmiah yang diyakini mampu menumbuhkan dan mengembangkan berbagai esensi tujuan pendidikan.

\section{Daftar Rujukan}

Abdul Majid dan Chaerul Rochman, Pendekatan Ilmiah dalam Implementasi Kurkulum 2013, Bandung: PT Remaja Rosdakarya, 2015.

Ahmadi, Menejemen Kurikulum Pendidikan Kecakapan Hidup, Yogyakarta: Pustaka Ifada, 2013.

Ali Salim Rashid Alghafri and Hairul Nizam Bin Ismail, The Effects of Integrating Creative and Critical Thinking on Schools Students' Thinking, International Journal of Social Science and Humanity, Voume 4 Nomor 6, November 2014.

Anderson, W. And Krathwohl, A Taxonomy For Learning Teaching, and Assesing A Revision Of Bloom's Taxonomy Of Education Objectives, New York: Longman, 2001.

Baharuddin at al, Teori Belajar dan Pembelajaran, Yogyakarta: Arruz Media, 2007.

Cucu Komara dan Deuis Fitni, Strategi Belajar Tuntas di Sekolah Dasar, Bandung: CV Sanjarindo Putra Utama, 1999.

Daryanto, Penelitian Tindakan Kelas dan Penelitian Tindakan Sekolah Beserta Contoh-contohnya, Yogyakarta: Gava Media, 2011.

David R. Krathwohl, "THEORY INTO PRACTICE", Volume 41, Number 4, Autumn 2002.

Deden Cahaya Kusuma, Jurnal Analisis Komponen Pengembangan Kurikulum 2013, (online)Tahun 2013. http://berita.upi.edu, diakses 3 Juni 2016.

Depdiknas, Pengembangan Model Pendidikan Kecakapan Hidup, Jakarta: Puskur Blitbang Depdiknas, 2007.

Edward De Bono,Theaching Thinking, terj. Soemardjo, Jakarta: Erlangga,1990.

Farida. S, "Korelasi Kemampuan Berpikir Kreatif dengan Prestasi Belajar Ips Siswa Sekolah Dasar", Pedagogi Jurnal Ilmiah Ilmu Pendidikan, Volume X, Nomor 2, November 2010.

FJ King et al, Higher Order Thinking Skills, A publication of the Educational Services Program, now known as the Center for Advancement of Learning and Assessment www.cala.fsu.edu. 
Hamruni, Strategi Pembelajaran, Yogyakarta: Insan Madani, 2012.

Hamzah B. Uno, Orientasi Baru Dalam Psikologi Pembelajaran, Jakarta: Bumi Aksara. 2006.

Jendela Pendidikan dan Kebudayaan, Perbaikan Kurikulum 2013, Kemampuan siswa Tidak dibatasi Taksonomi berpikir, Jakarta:Fokus edisi III, Juni 2016.

Kementerian Pendidikan dan Kebudayaan, Konsep dan Implementasi Kurikulum 2013, Paparan Wakil Menteri Pendidikan dan Kebudayaan R.I Bidang Pendidikan,Jakarta, t.p.14 Januari 2014, t.h.

--------, Peraturan Menteri Pendidikan dan Kebudayaan Repoblik Indonesia Nomor 81A Tahun 2013 tentang Implementasi Kurikulum, Jakarta:t.p. 2013.

--------, Peraturan Menteri Pendidikan dan Kebudayaan Nomor 54 tahun 2013 Tentang Standar Kompetensi Lulusan Pendidikan Dasar Dan Menengah.

-------, Penggembangan Pola Pikir Kurikulum 2013.t.p.

Kotler.P, at al. From Product to Costomers to the Human Spirit, New Jersey: John Wiley\&Sons, Inc., 20100.

Kowiyah, Kemampuan Berpikir Kritis, Jurnal Pendidikan Dasar, Volume 3 Nomor 5, Desember 2012.

Machin,A. "Implementasi Pendekatan Saintifik, Penanaman Karakter dan Konservasi pada Pembelajaran Materi Pertumbuhan", Jurnal Pendidikan IPA Indonesia, Volume:3 Nomor: 1, 2014.

Majid, Abdul, Pembelajaran Tematik Terpadu, Bandung: PT Remaja Rosdakarya, 2014.

Mardiyanto, Pendekatan Ilmiah dalam Kurikulum 2013, Semarang:Suara Merdeka,9 Agustus 2013.

Mulyasa, Pengembangan dan Implementasi Kurikulum 2013, Bandung: PT Remaja Rosdakarya, 2013.

Nana Syaodih Sukmadinata, Metode Penelitian Pendidikan, Bandung: PT Remaja Rosdakarya, 2007.

--------, Pengembangan Kurikulum Teori dan Praktik Bandung: PT Remaja Rosda Karya, 2009.

Nawawi, Hadari, Metode Penelitian Bidang Sosial, Yogyakarta: Gajah Mada University press, 1993.

Ni Wyn. Meliawati at al, "Analisis Penerapan Pendekatan Saintifik Terhadap Dalam Pembelajaran Berdasarkan Kurikulum 2013", e-Journal PGSD Universitas Pendidikan Ganesha Jurusan PGSD Volume: 3, Nomor: 1, (2015).

Nur Fajar Arief, Konsep dan Contoh Pendekatan Scientific dalam Pembeajaran, Jakarta:Tim Narasumber TOT Kurikulum 2013 Kemenag RI.t.h. 
Nyoman Paksa Adi Gama, "Pengaruh Implementasi Pendekatan Saintifik dengan Seting Inkuiri dalam Pembelajaran IPA terhadap Keterampilan Proses dan Hasil Belajar Siswa Kelas VII Smp Negeri 1 Singaraja".t.t.

Purwadhi, "Model Pembelajaran Berpikir dan Kemungkinan Implementasinya pada Pelajaran Akuntansi”. Jurnal Pendidikan Pengembangan Kurikulum dan Teknologi, Volume 5 Nomor 2,(2004).

Rahmatiah, "Pendekatan Saintifik sebagai Solusi dalam Pembelajaran Biologi" eBuletin, Sulawesi:Media Pendidikan dan LPMP Sulawesi Selatan, Edisi mei 2015.

Robert Burden and Marion Williams, Thinking Through The Curriculum, New York: Routledge, 1998.

Sajidan," Pembelajaran Biologi dengan Pendekatan Saintifik pada Implementasi Kurikulum 2013", Seminar Nasional Xi Pendidikan Biologi FKIP UNS, t.t.t.th.

Salih, Maria, "Developing Thinking Skills in Malaysian Science Students Via An Analogical Task", Journal of Science and Mathematics Education in Southeast Asia, Volume 33 Nomor 1, 2010.

Sudiarta, I G. P," Pengembangan pembelajaran berpendekatan tematik berorientasi pemecahan masalah matematika terbuka untuk mengembangkan kompetensi berpikir divergen, kritis dan kreatif". Jurnal Pendidikan dan Kebudayaan. Nomor. 069 volume 13 (Tahun. 2007).

Sukmadinata dan Nana Syaodih, Landasan Psikologi: Proses Pendidikan, Bandung: PT Remaja Rosda Karya, 2004.

Suyadi dan Dahlia, Implementasi dan Inovasi Kurikulum PAUD 2013, Bandung: PT Remaja Rosdakarya, 2014.

Suyono dan Hariyanto, Belajar dan Pembelajaran Teori dan Konsep Dasar, Bandung: PT Remaja Rosda Karya, 2012.

Tri Joko at al,"Peningkatan Kemampuan Berpikir Kritis" Jurnal Radiasi.Volume 3 Nomor 2, 2012.

Tri Joko,"Peningkatan Kemampuan Berpikir Kritis Melalui Model Pembelajaran Children Learning In Science (CLIS) pada Siswa Kelas VIII SMP Negeri 1 Mirit Tahun Pelajaran 2012/2013" Jurnal Radiasi.Volume 3 Nomor 2, 2012.

Varelas, M and Ford M, The scientific method and scientific inquiry: Tensions in teaching and learning, USA: Wiley InterScience, 2009.

Vernon G. Smith and Antonia Szymanski, "Critical Thinking: More Than Test Scores", NCPEA International Journal of Educational Leadership Preparation, Volume: 8, Nomor: 2 (October 2013).

Wina Sanjaya, Strategi Pemelajaran Berorientasi Standar Proses Pendidikan, Jakarta: kencana Prenada Media Group, 2006. 
Yaumi, Muhammad, Prinsip-prinsip Desain Pembelajaran diseuaikan dengan Kurikulum 2013 Jakarta:Kencana Prenadamedia Group, 2014.

Zurinal Z dan Wahdi Sayuti, Ilmu Pendidikan Pengantar dan Dasar-dasar Pelaksanaan Pendidikan, Jakarta: UIN Jakarta Press, 2006. 